\title{
REVIEW
}

\section{Salivary gland-like tumours of the breast: surgical and molecular pathology}

\author{
M Pia-Foschini, J S Reis-Filho, V Eusebi, S R Lakhani
}

J Clin Pathol 2003;56:497-506

Breast glands and salivary glands are tubulo-acinar exocrine glands that can manifest as tumours with similar morphological features, but that differ in incidence and clinical behaviour depending on whether they are primary in breast or salivary glands. Salivary gland-like tumours of the breast are of two types: tumours with myoepithelial differentiation and those devoid of myoepithelial differentiation. The first and more numerous group comprises a spectrum of lesions ranging from "bona fide" benign (such as benign myoepithelioma and pleomorphic adenoma), to low grade malignant (such as adenoid cystic carcinoma, low grade adenosquamous carcinoma, and adenomyoepithelioma), to high grade malignant lesions (malignant myoepithelioma). The second group comprises lesions that have only recently been recognised, such as acinic cell carcinoma, oncocytic carcinoma of the breast, and the rare mucoepidermoid carcinoma.

See end of article for authors' affiliations

..................

Correspondence to:

Professor S R Lakhani, The

Breakthrough Toby Robins

Breast Cancer Research

Centre, Institute of Cancer

Research, Mary-Jean

Mitchell Green Building,

Chester Beatty

Laboratories, Fulham Road,

London SW3 6JB, UK;

lakhani@icr.ac.uk

Accepted for publication

14 January 2003
B reast and salivary glands are both tubuloacinar exocrine glands sharing similar morphological features; consequently, it is reasonable to expect similarities in pathological processes. Comparing the histological classifications of breast and salivary gland tumours it is evident that the same types of neoplasms can arise at both sites. Salivary gland-like lesions of the breast can be subdivided into two main groups: tumours with myoepithelial differentiation and tumours devoid of or with scanty myoepithelial differentiation.

\section{BREAST TUMOURS WITH MYOEPITHELIAL DIFFERENTIATION}

Breast and salivary gland tumours can share morphological features, but often differ in incidence and clinical behaviour. This is particularly true of tumours showing myoepithelial differentiation, which are well known in salivary glands, whereas breast tumours showing pure myoepithelial differentiation or epimyoepithelial differentiation are rare. The first review on the subject was published by Hamperl in 1970. ${ }^{1}$ Since this seminal study, only single case reports or small series have been published. Two reviews on this subject were published recently. ${ }^{23}$ According to the data available in the literature it appears that the breast can harbour a spectrum of benign and malignant lesions showing pure myoepithelial or epithelial-myoepithelial differentiation. ${ }^{2-6}$ Because of the rarity of these neoplasms, only limited data on the molecular biology and genetics of breast salivary gland-like tumours have been published to date. ${ }^{4-16}$

$$
\begin{aligned}
& \text { "Breast tumours showing pure } \\
& \text { myoepithelial differentiation or } \\
& \text { epimyoepithelial differentiation are rare" }
\end{aligned}
$$

\section{Benign myoepithelioma}

Clinical and pathological features

Only rare examples of benign mammary tumours showing pure myoepithelial cell differentiation are on record. Toth ${ }^{17}$ described a 42 year old woman who presented with two breast nodules that were 2.3 and $1.8 \mathrm{~cm}$ in greatest dimension. On histology, the nodules were composed of an intraductal growth of spindle cells, with regular, oval nuclei. No mitoses or necrotic areas were seen. A similar case was described in 1989 by Enghardt and Hale. ${ }^{18}$ Briefly, it was a cystic tumour affecting a 43 year old woman. On histology, it was composed of spindle cells, devoid of atypical features. In addition, polygonal and flattened cells with the morphological and ultrastructural features of squamous elements lined the cystic cavity.

Benign myoepithelioma of the breast should be differentiated from other types of spindle cell tumours including sarcomatoid carcinomas. ${ }^{19-21}$

\section{Immunohistochemistry and electron} microscopy

Immunohistochemical analysis of breast myoepitheliomas demonstrates features of myoepithelial differentiation, of which immunoreactivity for smooth muscle actin (SMA) is the classic reaction. Myoepithelial differentiation may also be identified by electron microscopy; characteristic features include the presence of cytoplasmic bundles of myofilaments, desmosomes, and basal lamina. ${ }^{18}$

Abbreviations: $A A$, apocrine adenosis; $A C C$, adenoid cystic carcinoma; AcCC, acinic cell carcinoma; AdCC, adenoid cystic carcinoma; $\mathrm{AME}$, adenomyoepithelioma; CK, cytokeratin; EMA, epithelial membrane antigen; HMG, high mobility group; LGASC, low grade adenosquamous carcinoma; MEC, mucoepidermoid carcinoma; MM, malignant myoepithelioma; MMP, matrix metalloproteinase; OC, oncocytic carcinoma; PA, pleomorphic adenoma; PAS, periodic acid Schiff; SMA, smooth muscle actin 

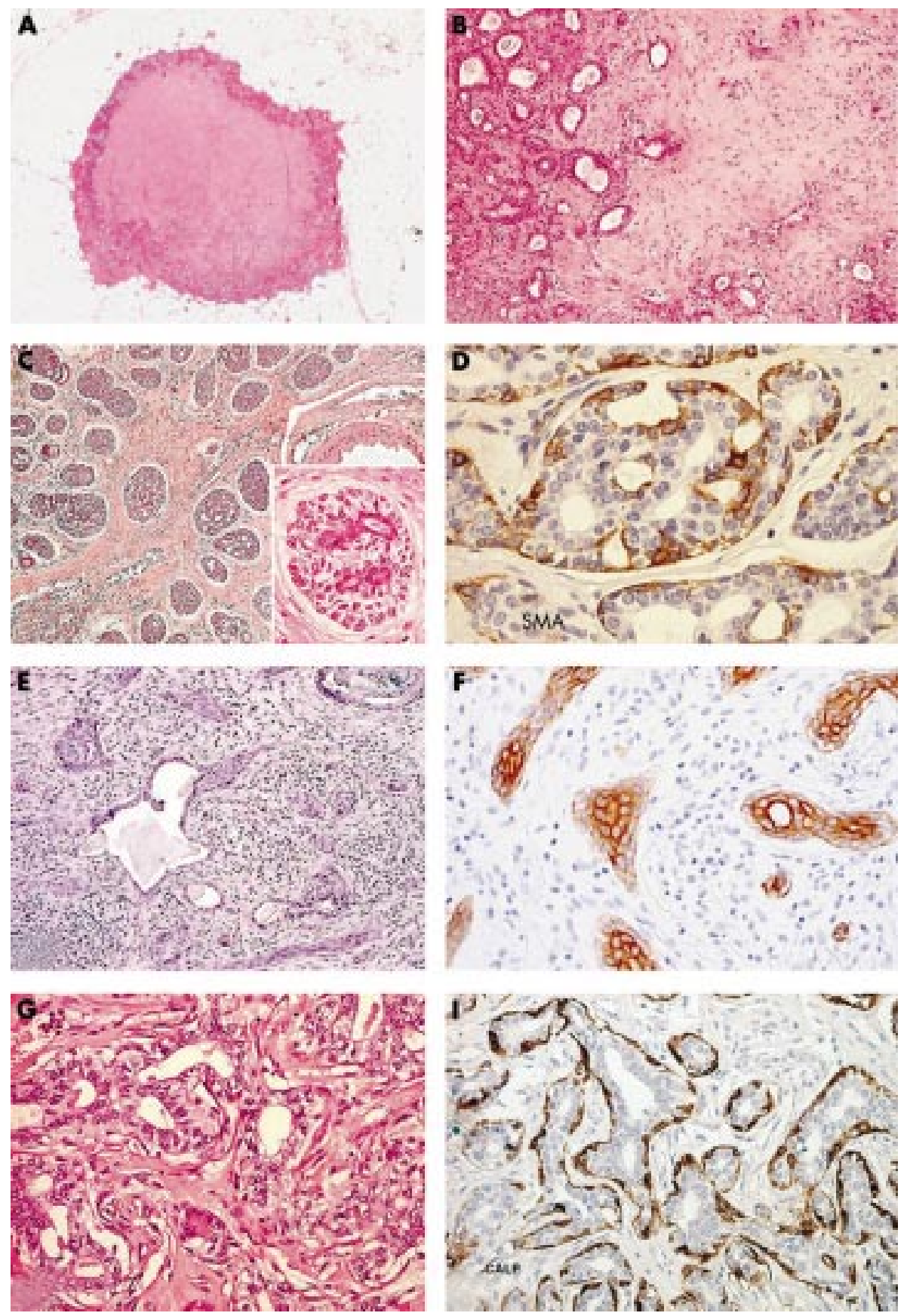

Figure 1 Benign/low grade malignant salivary gland-like tumours with myoepithelial differentiation. (A) Mammary pleomorphic adenoma has circumscribed margins and shows a central area of cartilaginous tissue; (B) medium power magnification disclosing glandular structures immersed in a myxoid stroma. (C) Adenoid cystic carcinoma (ACC) of the breast showing solid and cribriform architecture; inset, breast ACC is composed of basaloid cells that outline spaces containing basal-like material and of eosinophilic cells lining true glandular lumina; (D) staining for smooth muscle actin

(SMA) demonstrates myoepithelial cells. (E) Syringomatous

carcinoma/low grade adenosquamous carcinoma (SyC/LGASC) is composed of angulated glands located in desmoplastic stroma; (F) SyC squamous differentiation is frequent and contains high molecular weight keratin. (G) Breast adenomyoepithelioma (AME): glandular structures are formed by an inner layer of epithelial cells with eosinophilic cytoplasm and by an outer layer of myoepithelial cells with clear cytoplasm; $(\mathrm{H})$ staining for calponin demonstrates myoepithelial cells in breast AME.
To the best of our knowledge, no molecular analysis of benign myoepitheliomas has been published to date.

Prognosis and clinical management

Of the two reported cases of benign breast myoepithelioma, one recurred three times after the first excision, ${ }^{18}$ whereas no local recurrence was detected in the other. ${ }^{17}$ No nodal or distant metastases were reported. ${ }^{17} 18$

\section{Pleomorphic adenoma (mixed tumour)}

\section{Clinical and pathological features}

Pleomorphic adenoma (PA) is one of the most frequent tumours in salivary glands, whereas in human breast it is extremely rare. Narita and Matsuda found 54 published examples. ${ }^{22} \mathrm{PA}$ of the breast usually affects female patients, with only three cases reported in men. ${ }^{23-25}$ The age of the patients ranges from 19 to 85 years. ${ }^{825}{ }^{26}$ Breast PA is more frequently located in the subareolar region, and cases showing intraductal growth are on record..$^{25}$ An association with intraductal papillomas has been described. ${ }^{26}$ PA usually presents as small nodules of a few centimetres in the greatest dimension. The only exception is a tumour ${ }^{27}$ that measured $17 \mathrm{~cm}$ and weighted $2300 \mathrm{~g}$; however, this neoplasm was first noted 30 years before the surgical resection. Occasionally, PAs may be multifocal. ${ }^{26}$ Clinical and mammographical features can raise the suspicion of a carcinoma. ${ }^{28-30}$ Misdiagnosis of malignancy can also be performed on cytological specimens or on frozen section examination. ${ }^{28-30}$ Gross examination usually discloses a lobulated, well circumscribed hard nodule (fig lA), with a gritty cut surface. Histologically, breast PA is similar to its salivary gland counterpart (fig 1B). Its low power appearance is characterised by glandular structures and anastomosing cords of epithelial cells immersed in myxoid stroma, surrounded by a fibrous pseudocapsule that can be invaded or interrupted by nests of neoplastic cells. The glandular structures show an inner luminal layer of epithelial cells 
surrounded by an outer layer of myoepithelial cells. Myxoid stroma contains spindle or stellate cells. Cartilaginous and osseous areas are frequently encountered. ${ }^{7132}$

\section{Immunohistochemistry and molecular pathology}

Immunohistochemical studies have confirmed the dual nature of the neoplastic cells. Epithelial cells lining lumina of the neoplastic glandular structures are reactive to antibodies against low molecular weight cytokeratin, epithelial membrane antigen (EMA), and carcinoembryonic antigen. ${ }^{825} 26$ Antibodies against smooth muscle actin (SMA) and S-100 protein may highlight the outer rim of myoepithelial cells. In addition, myoepithelial markers, SMA, S-100 protein, calponin, and cytokeratin 14 (CK14) are positive in the spindle cells found in the myxoid and cartilaginous areas. ${ }^{782526}$ The dual nature-epithelial and myoepithelial—of the neoplastic cells in PA of the breast has been confirmed by ultrastructural observations. $^{8}$

As with their counterparts in salivary glands, benign salivary gland-like tumours of the breast with myoepithelial differentiation are usually diploid..$^{811-13}$

Pleomorphic adenomas of the salivary glands usually harbour chromosomal translocations ${ }^{33}{ }^{34}$; the most frequent rearrangements involve the long arms of chromosomes 8 (8q12), 12 (12q15), and 6 (6p21). ${ }^{33}$ Chromosomal translocations involving $8 \mathrm{q} 12$ usually lead to the activation of the pleomorphic adenoma gene l (PLAG1), a developmentally regulated zinc finger gene, whereas rearrangements of the other two genetic loci lead to the activation of high mobility group (HMG) protein genes, such as HMGI-C and HMGIY, which are located on $12 \mathrm{q} 15$ and $6 \mathrm{p} 21$, respectively. Even in pleomorphic adenomas with normal karyotypes, cryptic rearrangements of one of these genes may be identified. ${ }^{33}$ In contrast to the extensive analysis on chromosomal alterations in their salivary gland counterparts, the presence of recurrent gene rearrangements involving $8 \mathrm{q} 12,12 \mathrm{q} 15$, and $6 \mathrm{q} 2 \mathrm{l}$ in breast pleomorphic adenomas remains to be evaluated.

\section{Prognosis and clinical management}

The prognosis of breast PA is excellent. Indeed, in all cases reported patients were alive and well one to 12 years after surgery. Two cases recurred locally, ${ }^{25}{ }^{35}$ in one of which follow up was available, and the patient was alive and well 3.4 years after re-excision. Carcinoma ex-pleomorphic adenoma of the salivary gland shows obvious foci of malignant changes. ${ }^{36}$ Frank morphological malignant changes in putative PA of breast characterise matrix producing carcinoma, which can be regarded as one of the malignant features related to $\mathrm{PA}^{37}$ Hence, local excision of the lesion with clear margins is the recommended treatment in the literature. ${ }^{25}{ }^{37}$ To avoid unnecessary extensive surgical resections, a correct diagnosis is of utmost importance. Differential diagnosis of breast PA should include lesions showing similar morphological features but with more aggressive behaviour, such as squamous carcinomas with prominent myxoid stroma ${ }^{38}$ or matrix producing carcinoma. ${ }^{37}{ }^{39}$ Interestingly, in the series reported by Diaz et al the case of recurrent PA was particularly rich in myxoid stroma. ${ }^{25}$

\section{"The prognosis of breast pleomorphic adenoma is excellent"}

\section{Adenoid cystic carcinoma} Clinical and pathological features

Adenoid cystic carcinoma (AdCC) is a tumour composed of epithelial and myoepithelial cells similar to its salivary counterpart. Notwithstanding, breast AdCCs are rare and are not aggressive lesions. Breast AdCC presents as a nodule, ranging from 0.7 to $12 \mathrm{~cm}$, frequently located in the periareolar region. ${ }^{40}$ It usually affects adult female patients, aged from 38 to 81 years. Rare examples afflicting men or children are on record. ${ }^{41}$

Breast AdCC shows three different architectural patterns as the salivary analogue: trabecular-tubular, cribriform, and solid (fig 1C).

Two types of spaces characterise AdCC. The first type contains myxoid stroma or collagen fibres. The second type is composed of glands that contain a granular secretion of diastase resistant periodic acid Schiff (PAS) positive neutral mucosubstances.

Two different types of cells line these two types of spaces ( fig IC, inset). One type of cell, known as a basaloid cell, displays centrally located oval nuclei surrounded by a thin cytoplasmic rim. These cells line the spaces containing stroma and basal membrane-like material. The second cell type, characterised by round nuclei and eosinophilic cytoplasm, surrounds true glandular lumina containing mucinous material. AdCC of the breast can show areas of squamous differentiation ${ }^{42}{ }^{43}$; in addition, sebaceous features may also be found. ${ }^{43}$ AdCC of the breast has been described in association with adenomyoepithelioma ${ }^{44}$ and with low grade syringomatous (adenosquamous) carcinoma, ${ }^{45}$ thus suggesting the existence of a spectrum of epithelial-myoepithelial neoplasms.

Fine needle aspiration material from AdCC of the breast is usually abundant, and composed of large sheets, nests, or small aggregates of round to oval cells, sometimes with hyperchromatic nuclei. ${ }^{42}$ Giemsa staining highlights eosinophilic hyaline globules or cylinders of intercellular substance.

Breast AdCC should be differentiated from cribriform carcinoma $^{46}$ and from cylindromas arising in the skin overlying the breast. ${ }^{47}$

\section{Immunohistochemistry and molecular pathology}

Immunohistochemical analyses have demonstrated that basaloid cells are positive for vimentin and CKI4 and focally for myoepithelial markers, including SMA (fig ID), calponin, p63, ${ }^{48}$ and maspin. ${ }^{49}$ Ultrastructurally, basaloid cells show features of myoepithelial differentiation, ${ }^{50}{ }^{51}$ such as thin cytoplasmic filaments and well developed desmosomes; nevertheless, most frequently they present nondescript features with rare cytoplasmic organelles. The glandular cell type is usually positive for CK7 and shows short microvilli along the luminal surface.

Interestingly, the polarity of the different types of cells may be demonstrated by means of immunohistochemistry: basaloid cells usually express laminin, fibronectin, basal lamina related proteins, and type IV collagen, whereas luminal cells express proteins related to cell polarisation and epithelial differentiation, including fodrin, E-cadherin, and $\beta$ catenin. ${ }^{52}$

Adenoid cystic carcinomas of the breast seem to share similar chromosomal abnormalities with their related tumours in salivary glands, including alterations of $6 \mathrm{q} \cdot{ }^{53}$ Of the 28 cases of adenoid cystic carcinoma evaluated thus far, ${ }^{12}{ }^{13}$ only two cases showed an aneuploid DNA content. ${ }^{12}$

TP53 gene mutation $\mathrm{s}^{54}$ have been demonstrated in salivary gland adenoid cystic carcinomas; however, there are no data for breast lesions. Holst and colleagues ${ }^{55}$ showed that overexpression of KIT, a tyrosine kinase receptor involved in cell growth, is a relatively frequent event in salivary gland adenoid cystic carcinomas. Because of the Food and Drug Administration approval of STI-57l, a drug that inhibits the tyrosine kinase activity of KIT, it would be interesting to look for overexpression or gene amplification of this tyrosine kinase receptor in adenoid cystic carcinomas of the breast.

\section{Prognosis and clinical management}

The prognosis of breast AdCC is usually good. Axillary lymph node metastases have been reported rarely. ${ }^{50} 56^{57}$ The rare local recurrences probably result from incomplete excision of the primary tumour. Distant metastases are $\operatorname{rare}^{58}$ and usually 
affect the lungs. ${ }^{58}$ Salivary gland AdCCs are graded according to the histological architectural pattern. The same grading system was applied in breast AdCCs by Ro et al, who found that recurrences and metastases were restricted to patients with grade II or grade III AdCC. ${ }^{56}$ However, Lamovec and colleagues $^{42}$ and Kleer et al, ${ }^{59}$ whose patients did not experience recurrences or metastatic dissemination, regardless of the histological grade of the lesions, did not confirm these results. It is generally accepted that AdCC of the breast should be treated with simple mastectomy, with no axillary dissection. ${ }^{59}$ Recently, Shin and Rosen ${ }^{60}$ reported nine putative cases of the so called solid variant of mammary AdCC, which is characterised by a predominantly solid architecture. Axillary lymph node metastases were present in two of the six patients in whom axillary dissection was performed. Follow up information was available for seven patients, all of whom were disease free two to 88 months after surgery. These authors concluded that the solid basaloid features in breast AdCC are indicative of a tendency to develop axillary lymph node metastases and suggested that axillary dissection should be performed in patients with these features. ${ }^{60}$ However, it should be noted that evidence of epimyoepithelial differentiation in these neoplasms is weak ( seven of nine cases were negative for smooth muscle myosin heavy chain) ${ }^{60}$ so that it is still unclear whether these tumours are variants of AdCC or basaloid carcinomas.

\section{Syringomatous carcinoma (or low grade adenosquamous carcinoma) Clinical and pathological features}

This lesion, first described by Rosen and Ernsberger ${ }^{61}$ as low grade adenosquamous carcinoma (LGASC), is a breast tumour morphologically similar to syringomatous carcinoma ( $\mathrm{SyC}$ ) of the salivary glands and skin. Thus, a common terminology would be desirable. ${ }^{3}$ It affects adult female patients, presenting with palpable masses ranging from 1.5 to $8 \mathrm{~cm}$ at their greatest axis. Histologically, it is composed of angulated glands lined by an inner layer of epithelial cells and by an outer layer of myoepithelial cells. ${ }^{36-63}$ immersed in desmoplastic stroma (fig 1E). Squamous differentiation is frequent. LGASC can be associated with AME and lesions named "infiltrative epitheliosis" by Azzopardi. ${ }^{40}$

\section{Molecular pathology}

Immunohistochemical analysis has provided conflicting data regarding the immunoprofile of these neoplasms. Although some authors have reported the expression of myoepithelial markers, including actin (HHF35 and 1A4), calponin, S-100 protein, high molecular weight cytokeratin (CK14 and CK5/6) (fig lF), p63, p-cadherin, and maspin, ${ }^{64}$ others have failed to confirm this. As expected, these neoplasms are consistently negative for oestrogen receptors and progesterone receptors.

No study on the molecular profile of these rare neoplasms has been carried out hitherto. In the largest series of LGASCs reported so far, Drudis and colleagues ${ }^{62}$ demonstrated the expression of cathepsin D (a lysosomal proteinase putatively involved in metastatic dissemination), c-erb-B2/Her-2-neu, and p53 in 39\%, 46\%, and $13 \%$ of these neoplasms, respectively. None of these markers proved to have prognostic relevance. $^{62}$

\section{Prognosis and clinical management}

Prognosis is generally good-only one has patient died of the disease ${ }^{63}$ Nevertheless, these tumours recur locally and can be widely invasive..$^{6163}$

\section{Adenomyoepithelioma}

\section{Clinical and pathological features}

Adenomyoepithelioma (AME) of the breast is a biphasic tumour, morphologically and immunohistochemically identical to epithelial-myoepithelial cell carcinoma of the salivary gland. ${ }^{65}$ It was first recognised in the breast by Hamperl, ${ }^{1}$ and later described by Kiaer and colleagues ${ }^{66}$ and Eusebi et al. ${ }^{67}$ AME usually affects adult female patients and presents as a palpable nodule, ranging from 1 to $7 \mathrm{~cm}$ at its greatest axis. ${ }^{2368}$ Rare cases have been described in men. ${ }^{69} 70$ On histological examination, AME may show distinctive architectural growth patterns - tubular, papillary, or solid ${ }^{2368}$-and tumours often show a combination of any of these. Regardless of the predominant growth pattern, AME is composed of two cell types, myoepithelial and epithelial (fig lG). The myoepithelial component is composed of cuboidal to spindle shaped cells, with round to elongated nuclei with very small nucleoli and clear, glycogen rich, cytoplasm. This cell type generally constitutes the outer layer of the tubular structures, or the solid areas. The epithelial component is composed of columnar cells, with eosinophilic cytoplasm, which line the lumina of the tubular and papillary structures.

"It may be more appropriate to abandon the use of
apocrine adenosis in the context of
adenomyoepithelioma for those lesions described by
Eusebi et al and to report them as tubular
adenomyoepithelioma"

In contrast to salivary gland lesions, breast AME frequently shows glandular proliferation formerly known as "apocrine adenosis" (AA), ${ }^{67}$ which is characterised by roundish glandular structures lined by two cell types. The luminal layer is composed of eosinophilic cells showing morphological and immunohistochemical features of apocrine cells. The outer cell layer is composed of clear cells, with the morphological and immunohistochemical profile of myoepithelial cells. ${ }^{68} \mathrm{AA}$ is seen mostly at the periphery of AME, or intermingled with $\mathrm{it}^{3}{ }^{377172}$ indicating that AA is probably part of the morphological spectrum of AME. Because AA can precede AME, ${ }^{71}$ it is important to differentiate it from similar lesions of the breast, such as tubular carcinoma and microglandular adenosis. ${ }^{72}$ Thus, recognition of the dual cell proliferation (epithelial and myoepithelial) lining the glandular lumina of AA is an important diagnostic clue. Most pathologists use the same name (that is, apocrine adenosis) to describe apocrine changes in sclerosing adenosis. ${ }^{73}$ It may be more appropriate to abandon the use of AA in the context of AME for those lesions described by Eusebi and colleagues ${ }^{67}$ and to report to them as "tubular AME".

\section{Molecular pathology}

Immunohistochemical analysis demonstrates that outer clear cells are positive for myoepithelial markers, such as SMA, calponin (fig 1H), S-100 protein, CK14, p63, ${ }^{48}$ and maspin. ${ }^{49}$ At variance, luminal cells are strongly positive for low weight cytokeratins, such as CK7 and CK19, EMA, and often apocrine markers.

To date, there have been only rare reports on the DNA content or the classic cytogenetic profile of typical adenomyoepitheliomas. ${ }^{14}$ Thirty cases of epithelialmyoepithelial carcinoma, the counterpart of adenomyoepithelioma in salivary glands, were evaluated by cytophotometry. ${ }^{75}$ Of these cases, 27 proved to be DNA diploid, whereas three were DNA aneuploid. ${ }^{75}$ Interestingly, in these neoplasms, aneuploidy and cell proliferation were more frequently found in the myoepithelial cell layer than in the luminal component. ${ }^{77}$ Similar findings were reported by Trojani et al, ${ }_{11}^{11}$ who reported on a malignant adenomyoepithelioma with lung metastases, which showed a DNA diploid epithelial population and DNA tetraploid myoepithelial cells. Taken together, these findings ${ }^{11} 75-77$ have led some authors ${ }^{75} 78$ to assume that in epithelial-myoepithelial carcinomas, the luminal component may represent a more differentiated cell 

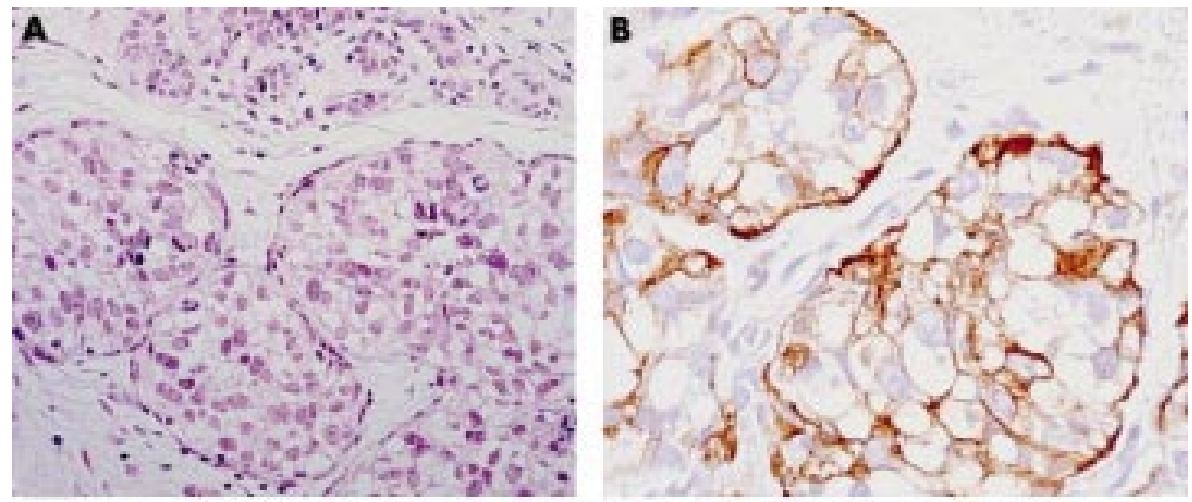

Figure 2 Malignant myoepithelioma/myopithelial carcinoma. (A) Malignant myoepithelioma (MM) with intralobular growth; (B) myoepithelial differentiation is confirmed by anti-smooth muscle actin antibody; (C) $M M$ is composed of a solid proliferation of extremely atypical cells; (D) foci of squamous differentiation are occasionally seen (arrow); (E) MM with spindle cell morphology (note the high mitotic activity). (F) Grade III invasive ductal carcinoma with myoepithelial differentiation.
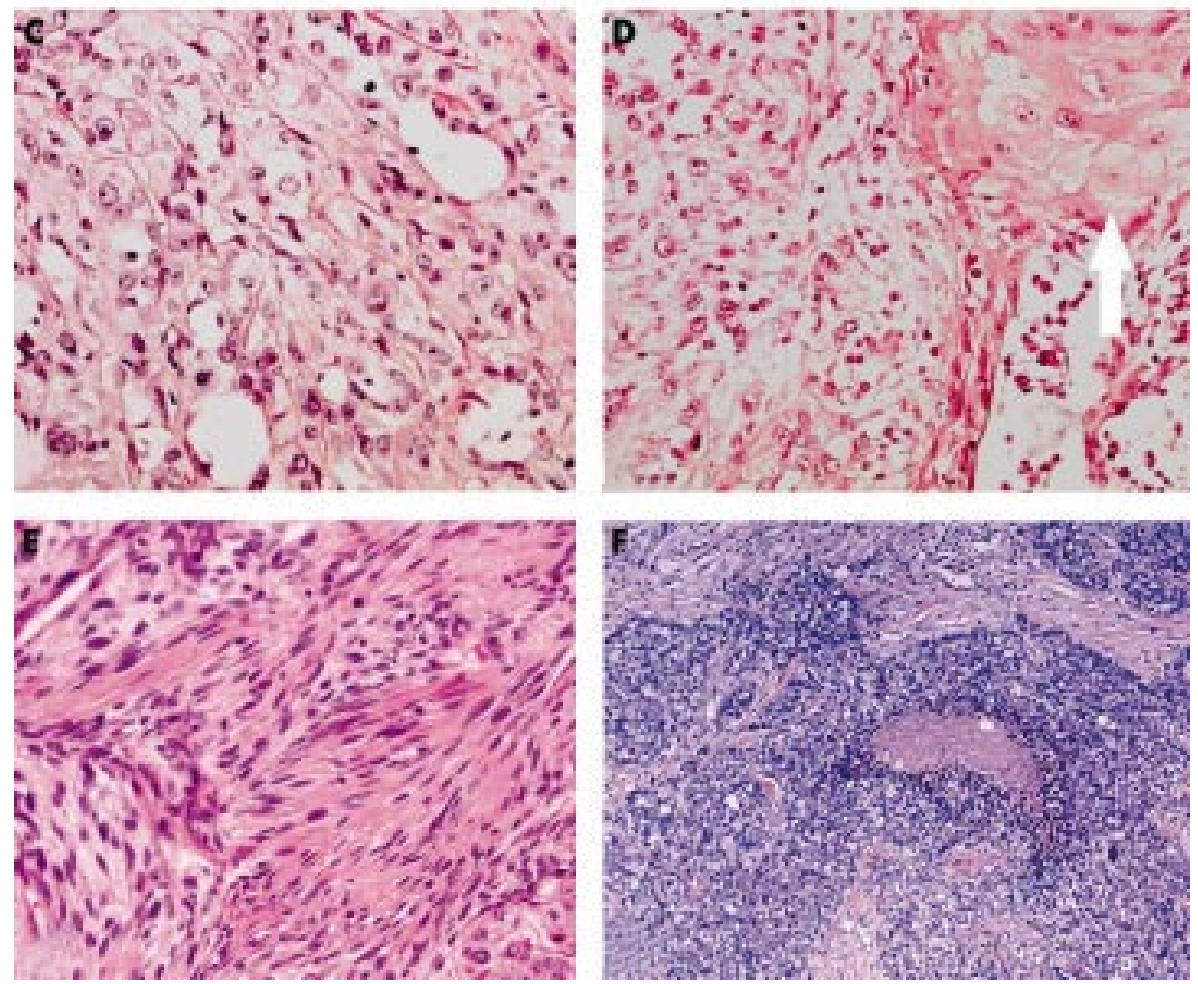

type and that these cells might result from differentiation of the myoepithelial cells.

\section{Prognosis and clinical management}

The prognosis of AME of the breast is usually good. Local recurrences can occur when the primary tumour has been incompletely excised. ${ }^{79}$ However cases of AME presenting solid areas with anaplastic features, and AME associated with clear carcinomatous features $^{80-85}$ are a distinctive occurrence. The malignant features present in AME most frequently consist of myoepithelial cells, showing features identical to those found in pure malignant myoepitheliomas or in sarcomatoid carcinomas. ${ }^{3}$ Such cases have been reviewed recently ${ }^{86}$ by Bult et al, who found distant metastases and local recurrences in more than $30 \%$ of cases. Lungs were the most frequent sites of distant metastases.

\section{Malignant myoepithelioma}

\section{Clinical and pathological features}

As previously stated, features of malignant myoepithelioma (MM) can be seen in association with AME ${ }^{80} 8587$ whereas only rare cases of pure MM have been reported ${ }^{88-97} \mathrm{MM}$ of the breast presents as painless nodules, in patients greater than 50 years of age. Morphologically, MMs of the breast show protean histological features. Rare cases have a predominant intraductal ${ }^{95}$ or intralobular ${ }^{96}$ growth pattern (fig $2 \mathrm{~A}, \mathrm{~B}$ ), and one case was mainly composed of cells with clear cytoplasm. ${ }^{89}$ Most of the previously reported cases were composed of a solid proliferation of spindle cells, with eosinophilic cytoplasm and very atypical nuclei. In some of the cases, features of squamous differentiation were also found (fig 2C,D). ${ }^{88}$ In all cases, myoepithelial cell differentiation was demonstrated by ultrastructural studies or immunohistochemistry. MM appears to have an aggressive biological behaviour. Apart from one study reported in abstract format, ${ }^{98}$ in which 17 of 18 patients were disease free after treatment, most patients with MM reported so far have developed distant metastatic spread, which resulted in death. ${ }^{3}$ The clinical and morphological features of MM are very similar to those of monophasic sarcomatoid carcinoma" (fig $2 \mathrm{E})$, suggesting that $\mathrm{MM}$ and a proportion of so called "sarcomatoid carcinomas" are probably part of the same entity. ${ }^{38} 99$

Recent reports have expanded the spectrum of myoepithelial cell carcinoma of the breast ${ }^{4-6910100}$ because myoepithelial cell differentiation has been demonstrated within and in association with grade III breast carcinomas of no special type (fig 2F). These tumours are composed of large, solid sheets of extremely atypical neoplastic cells, with central necrotic areas. Neoplastic cells are round to oval, with a high nuclearcytoplasmic ratio, irregular nuclei, and prominent nucleoli. 
Focal squamous cell differentiation may also be seen. ${ }^{9}$ We have occasionally seen cases where myoepithelial cell features (including positivity for $\alpha \mathrm{SMA}$ ) were observed in the same cells showing intense EMA production.

Finally, it should be mentioned that rare cases of MM with oncocytic features have been reported. ${ }^{101}$ In salivary glands, oncocytic features have been described only in benign myoepithelial tumours. ${ }^{102}$

\section{Molecular pathology}

Immunohistochemistry shows immunoreactivity for myoepithelial markers, such as SMA, ${ }^{69}$ calponin, caldesmon, ${ }^{6}$ S- 100 protein, ${ }^{9}$ glial fibrillary acidic protein, ${ }^{9}$ and CK14. ${ }^{69}$ Myoepithelial cell differentiation is evident on ultrastructural examination also. ${ }^{10} 9397$

It has been shown that $2-18 \%$ of breast carcinomas may have distinctive and convincing immunohistochemical myoepithelial features. ${ }^{4}$ Recently, Perou et al described four distinctive patterns of gene expression clustering in breast carcinomas by means of cDNA microarray technology. ${ }^{15}$ According to this study, ${ }^{15}$ breast carcinomas may be classified into four distinct gene expression patterns: (1) a luminal epithelial/oestrogen receptor positive pattern; (2) a normal breast-like pattern; (3) a c-erb-B2 positive pattern; and (4) a basal cell/myoepithelial cell pattern. It is noteworthy that this group also showed a correlation between basal and c-erb-B2 positive groups with an aggressive biological behaviour. ${ }^{16}$

\section{"Despite the high grade histological appearance and aggressive biological behaviour displayed by myoepithelial carcinomas, the number of chromosomal gains and losses was lower than that seen in true luminal carcinomas of the breast of the same histological grade"}

Two comprehensive studies on chromosomal gains and losses by means of comparative genomic hybridisation of myoepithelial carcinomas of the breast have been reported. ${ }^{56}$ Moreover, despite the high grade histological appearance and aggressive biological behaviour displayed by myoepithelial carcinomas, ${ }^{561016}$ the number of chromosomal gains and losses was lower than that seen in true luminal carcinomas of the breast of the same histological grade. ${ }^{56}$ It has been shown that loss of heterozygosity and allelic imbalance can appear independently in the luminal and myoepithelial cells of normal breast lobules. ${ }^{103}$ Strikingly, myoepithelial differentiation in malignant breast neoplasms is relatively infrequent. ${ }^{4}$ These findings prompted researchers to suggest that myoepithelial cells seem to be resistant to transformation. ${ }^{403-105}$ It should be noted that myoepithelial cells have been regarded as putative natural tumour suppressor cells. ${ }^{4{ }^{103-105}}$ Sternlicht et al showed that because of their strategic positioning (between luminal cells and breast stroma) and their capacity to produce and remodel basal membrane, myoepithelial cells may play a paracrine suppressing role in invasion and metastasis. ${ }^{104} 105$ Myoepithelial cells and myoepithelial tumours of the breast, including adenomyoepithelioma, adenoid cystic carcinoma, epithelial-myoepithelial carcinoma, and malignant adenomyoepithelioma, produce a complex profile of matrix metalloproteinases (MMPs), ${ }^{104}{ }^{105}$ MMP inhibitors, and serine protease inhibitors, ${ }^{49}{ }^{105}$ such as maspin, which might account for their resistance to transformation stimuli.

There have been reports ${ }^{48}{ }^{64} 106{ }^{107}$ that p63, a p53 homologue nuclear transcription factor whose gene is located on $3 \mathrm{q} 27$, is consistently expressed in normal myoepithelial and basal cells of the breast, ${ }^{4864106107}$ in myoepithelial lesions, ${ }^{48}{ }^{64106-108}$ including salivary gland-like tumours, and in metaplastic carcinomas of the breast. ${ }^{48^{64}{ }^{106-108}}$ Unlike p53, p63 does not seem to be a tumour suppresser gene. ${ }^{48}$ Dominant negative isoforms of p63 ( $\Delta \mathrm{N}-\mathrm{p} 63)$ generated by alternative splicing of the TP63 gene lack the N-terminal transactivating region. ${ }^{48}$ Interestingly, $\Delta \mathrm{N}-\mathrm{p} 63$ can bind to p53 reporter genes, but is unable to transactivate them, thus providing an alternative mechanism to overcome p53 driven cell cycle arrest and apoptosis. $^{48}$ It is of note that $3 \mathrm{q} 27$ is one of the most frequently amplified regions in squamous cell carcinomas of the skin and the head and neck region ${ }^{48}$; accordingly, $\Delta \mathrm{N}$-p63 is frequently overexpressed in these neoplasms. ${ }^{48}$ Recently, Patturajan and colleagues ${ }^{109}$ demonstrated another mechanism that might account for the oncogenetic role played by this p53 homologue. These authors ${ }^{109}$ elegantly demonstrated that $\Delta \mathrm{N}$-p63 might block the phosphorylation of $\beta$ catenin, leading to its nuclear accumulation. This aberrant subcellular localisation of $\beta$ catenin may activate its signalling pathway, ${ }^{109}$ providing another molecular pathway for the oncogenetic activity of $\Delta \mathrm{N}$-p63.

\section{Prognosis and clinical management}

The report by Tsuda et al has shown that tumours with a myoepithelial differentiation harbour distinctive metastatic patterns, with a high prevalence of pulmonary and cerebral metastases, ${ }^{10}$ and a poor prognosis. ${ }^{10}$ Most importantly, these clinical biological differences were independently found by means of conventional morphological ${ }^{9}{ }^{10}$ and high throughput molecular profiling of breast tumours. ${ }^{16}$

\section{BREAST SALIVARY GLAND-LIKE TUMOURS DEVOID OF MYOEPITHELIAL DIFFERENTIATION}

This second group includes rare and recently recognised breast lesions-acinic cell carcinoma (AcCC), oncocytic carcinoma (OC), and mucoepidermoid carcinoma (MEC). The presence of myoepithelial cell differentiation in salivary gland MEC has been a matter of debate. ${ }^{110-113}$ Hanna et al demonstrated convincing immunohistochemical and ultrastructural features of myoepithelial differentiation in MEC of the breast. ${ }^{113}$ Most importantly, these authors found that intermediate cells of breast MECs contained focal peripheral myofilaments with dense bodies and pinocytic vesicles associated with centrally aggregated tonofilaments; these findings led the authors to suggest that intermediate cells may be modified myoepithelial cells. ${ }^{113}$ Nevertheless, because myoepithelial cells are not the predominant elements in MECs, these tumours are included in this second group. ${ }^{112}$

\section{Acinic cell carcinomas}

\section{Clinical and pathological features}

AcCC of the salivary gland is a tumour characterised by serous acinar differentiation, with zymogen-type cytoplasmic granules, and immunoreactivity for amylase, lysozyme, and $\alpha \mathrm{l}$ antichymotrypsin. ${ }^{114}$ AcCC of the breast is similar to its salivary gland counterpart at the morphological, immunohistochemical, and ultrastructural levels. ${ }^{115-119}$ However, some differences should be pointed out: whereas AcCCs of the salivary glands are grossly circumscribed, have pushing borders, and display solid and cystic areas, AcCCs of the breast are solid and may be poorly circumscribed and infiltrating. ${ }^{117}{ }^{119}$ In addition, the architectural growth patterns may be different in breast and salivary gland AcCCs: no cases of AcCC of the salivary glands with an infiltrating microglandular pattern have been described, whereas this architectural pattern was seen by Damiani and colleagues ${ }^{117}$ and Coyne and Dervan ${ }^{119}$ in AcCCs of the breast. All breast AcCCs have affected women, most frequently in their 6th decade of life, and presented as palpable nodules measuring 2 to $5 \mathrm{~cm}$ at their greatest diameter. AcCCs are composed of cells of the same type (fig 3A,B), which are characterised by central round nuclei with prominent nucleoli, and abundant granular, eosinophilic to amphophilic cytoplasm. Coarse granules may be highlighted by PAS after 

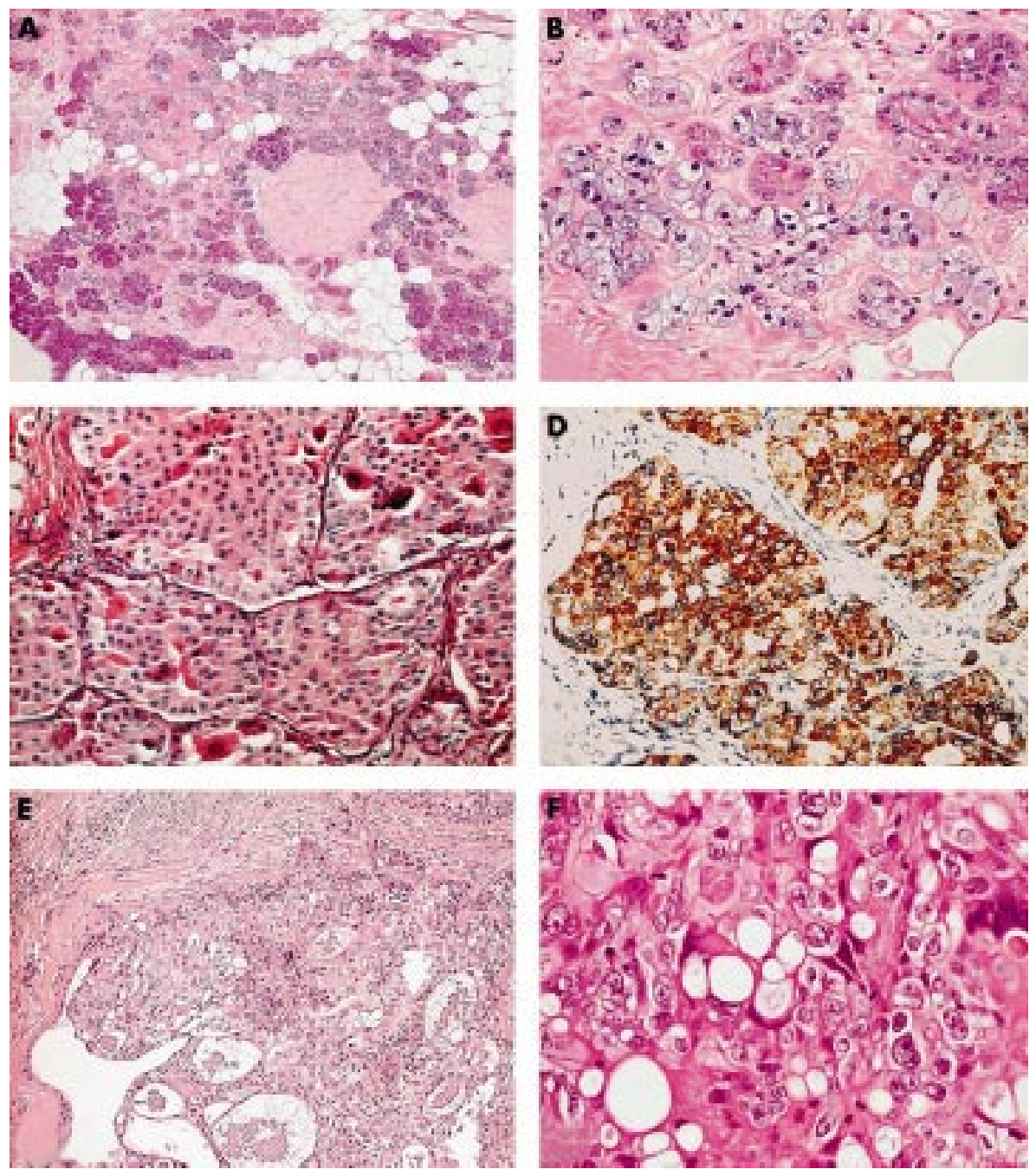

Figure 3 Salivary gland-like tumours without myoepithelial differentiation. (A) Acinic cell carcinoma (AcCC) with microglandular growth; (B) cells have a granular eosinophilic to amphophilic cytoplasm; some cells also show foamy cytoplasm (courtesy of $\mathrm{Dr}$ IO Ellis). (C) Breast oncocytic carcinoma (OC) is composed of cells with granular eosinophilic cytoplasm; (D) anti-mitochondrion antibody strongly stains this case of breast OC. (E) Low grade mammary mucoepidermoid carcinoma (MEC) composed of neoplastic nests outlined by basaloid cells and centrally containing epidermoid and mucous secreting cells; (F) high power magnification of high grade mammary MEC showing a complex admixture of basaloid and epidermoid elements and mucous secreting cells. diastase pretreatment. Clear cells are frequently found. The mitotic index is high, up to 15/10 high power fields.

Interestingly, Hirokawa et al demonstrated features of acinar cell differentiation in secretory carcinoma of the breast, suggesting that a considerable number of acinic cell carcinomas might have been overlooked. ${ }^{118}$

Immunohistochemistry and electron microscopy

Immunoreactivity for amylase, lysozyme, EMA, and S-100 protein can help to differentiate AcCCs from conventional invasive ductal carcinoma of the breast. Ultrastructural examination discloses electron dense granules similar to those seen in parotideal acinar cells. ${ }^{15-117119}$

\section{Prognosis and clinical management}

The prognosis of AcCC of the breast appears to be good. Only three of 11 patients who underwent axillary dissection developed lymph node metastases. ${ }^{115-119}$ Apart from one patient who developed liver metastases and died of disease three years after her initial diagnosis, ${ }^{119}$ none of the other nine patients with follow up has died of disease. ${ }^{115-118}$ Nevertheless, these results should be interpreted with caution because the length of follow up was limited to a maximum of five years.

\section{Oncocytic carcinoma}

Clinical and pathological features

Oncocytic tumours can arise in various organs, including the breast and salivary glands. Only rare examples of breast OC have been reported in the literature, ${ }^{120}{ }^{121}$ but we feel that its real incidence is much higher. Breast OC might have been overlooked, and probably misdiagnosed as apocrine carcinoma. ${ }^{120}$ Four cases of breast OC are on record, ${ }^{120}{ }^{121}$ one of which affected a male patient. All previously reported cases affected patients older than 60 years, and presented as palpable nodules, the largest was $2.8 \mathrm{~cm}$ in major diameter. Histologically, these tumours are characterised by solid nests and glandular structures composed of round cells, with eosinophilic and finely granular cytoplasm, centrally located round nuclei, and prominent nucleoli (fig 3C). One case was associated with in situ duct carcinoma, with papillary architecture. $^{120}$

"Only rare examples of breast oncocytic carcinoma have been reported in the literature, but we feel that its real incidence is much higher"

Immunohistochemistry and electron microscopy

Immunohistochemistry with an antimitochondrial antibody showed strong, granular, and diffuse positivity (fig 3D), confirming the oncocytic nature of the cells. Staining with this antibody could be used as an adjunct for the differential diagnosis with other types of breast carcinomas with granular cells. ${ }^{120}$ The presence of numerous mitochondria has also been confirmed by ultrastructural examination.

Prognosis and clinical management

Prognosis appears to be good ${ }^{120}{ }^{121}$ because all of the reported patients were alive and well, although the number of reported cases is too small to allow conclusions. 
Take home messages

- Salivary gland-like tumours of the breast can be divided into two groups: tumours with myoepithelial differentiation and those without myoepithelial differentiation

- Tumours with myoepithelial differentiation are rare but comprise a wide spectrum of lesions ranging from benign (such as benign myoepithelioma and pleomorphic adenoma), to low grade malignant (such as adenoid cystic carcinoma, low grade adenosquamous carcinoma, and adenomyoepithelioma), to high grade malignant lesions (malignant myoepithelioma)

- Tumours without myoepithelial differentiation comprise three types of lesions, which have only recently been recognised, namely: (1) acinic cell carcinoma, (2) oncocytic carcinoma of the breast, and (3) the rare mucoepidermoid carcinoma

\section{Mucoepidermoid carcinoma}

\section{Clinical and pathological data}

MEC is one of the most frequent types of salivary gland carcinoma, and it is composed of a mixture of basaloid, intermediate, epidermoid, and mucinous cells. It was first described by Foote et al in 1945, ${ }^{122}$ who recognised two distinct forms: a low grade and a high grade form. Recently, a putative prognostically significant histopathological grading system was proposed. ${ }^{123}$ If one applies a stringent grading system to breast MECs, such as that used for their salivary gland counterparts, only rare examples of low and high grade MEC are on record. ${ }^{113}$ 124-135

\section{Low grade mammary MEC}

Ten patients have been described, all were women, ranging in age from 31 to 81 years. ${ }^{113}{ }^{124}{ }^{125}{ }^{134}$ Histological examination of low grade breast MEC discloses well circumscribed, sometimes cystic lesions, filled with mucins. Neoplastic nests and cysts are lined at the periphery by basaloid cells and intermediate cells. Epidermoid or mucous secreting cells are usually found in the central aspects (fig 3E).

\section{High grade MEC}

High grade MECs usually affect women from 27 to 72 years of age. ${ }^{125-132}{ }^{134}$ Until recently, ${ }^{136}$ the criteria proposed for the diagnosis of high grade MEC were not well defined. Thus, possibly, this group encompasses different entities of high histological grade, which are composed of a complex admixture of glandular structures with mucin production, foci of squamous differentiation, and so called intermediate cells, with a pronounced predominance of the squamous and intermediate cell components ${ }^{125-132}{ }^{134}$ (fig $3 \mathrm{~F}$ ).

\section{Immunohistochemistry and molecular pathology}

Immunohistochemical analysis of MECs demonstrates the same "zoning phenomenon" described in low grade MEC of the salivary glands ${ }^{112}$ : anti-CK14 stains basaloid elements, which are usually seen at the periphery of the nests and cyst, whereas anti-CK7 stains mucoid cells bordering the cystic spaces or located at the centre of the solid nests. Anti-CK20 is usually negative. Myoepithelial cell markers are rarely positive in occasional cells. p63 shows a differential expression in the various components of MECs, with consistent expression in the squamous and intermediate cells, and a lack of expression in the mucinous areas (JS Reis-Filho and RHW Simpson, unpublished results, 2002). In contrast to salivary gland cases, low grade breast MECs are not positive for mitochondrial markers (V Eusebi and M Pia-Foscini, personal observation, 2002).

No studies on the molecular pathology of breast MECs have been reported to date.
Prognosis and clinical management Low grade MECs

Nine patients were treated with radical mastectomy and one with simple mastectomy. Axillary metastases were described in one patient ${ }^{114}$ and no distant metastases were reported. All the patients were alive and well 10 to 120 months after surgery.

\section{High grade MECs}

This heterogeneous group of neoplasms has a highly aggressive behaviour; metastases to the axillary lymph nodes and to distant organs are frequent, resulting in a short survival (from six to 30 months). ${ }^{124-132}{ }^{134}$

\section{ACKNOWLEDGEMENTS}

Dr JS Reis Filho is the recipient of the Gordon Signy Foreign Fellowship in Pathology 2001 and is partially supported by a PhD grant from the Portuguese Science and Technology Foundation (Fundação para A Ciência e a Tecnologia (FCT), Portugal) reference SFRH/BD/5386/ 2001

\section{Authors' affiliations}

M Pia-Foschini, V Eusebi, Department of Pathology, University of Bologna, at Ospedale Bellaria, Bologna, I-40139 Italy

J S Reis-Filho' The Breakthrough Toby Robins Breast Cancer Research Centre, Institute of Cancer Research, Mary-Jean Mitchell Green Building, Chester Beatty Laboratories, London SW3 6JB, UK

S R Lakhani, The Department of Anatomic Pathology, The Royal Marsden Hospital, London SW3 6JJ, UK

\section{REFERENCES}

1 Hamperl H. The myothelia (myoepithelial cells). Normal state; regressive changes; hyperplasia; tumors. Curr Top Pathol 1970;53:161-220.

2 Tavassoli FA. Myoepithelial lesions of the breast. Myoepitheliosis, adenomyoepithelioma, and myoepithelial carcinoma. Am J Surg Pathol $1991 ; 15: 554-68$

3 Foschini MP, Eusebi V. Carcinomas of the breast showing myoepithelial cell differentiation. A review of the literature. Virchows Arch 1998;432:303-10.

4 Lakhani SR, O'Hare M. The mammary myoepithelial cell-Cinderella or ugly sister? Breast Cancer Res 2001;3:1-4.

5 Jones C, Foschini MP, Chaggar R, et al. Comparative genomic hybridization analysis of myoepithelial carcinoma of the breast. Lab Invest 2000;80:831-6.

6 Jones C, Nonni AV, Fulford L, et al. CGH analysis of ductal carcinoma of the breast with basaloid/myoepithelial cell differentiation. $\mathrm{Br} J$ Cancer 2001;85:422-7.

7 Chen KT. Pleomorphic adenoma of the breast. Am J Clin Pathol 1990;93:792-4.

8 Ballance WA, Ro JY, el-Naggar AK, et al. Pleomorphic adenoma (benign mixed tumor) of the breast. An immunohistochemical, flow cytometric, and ultrastructural study and review of the literature. Am J Clin Pathol 1990;93:795-801.

9 Tsuda H, Takarabe T, Hasegawa T, et al. Myoepithelial differentiation in high-grade invasive ductal carcinomas with large central acellular zones. Hum Pathol 1999;30:1134-9.

10 Tsuda H, Takarabe T, Hasegawa F, et al. Large, central acellular zones indicating myoepithelial tumor differentiation in high-grade invasive ductal carcinomas as markers of predisposition to lung and brain metastases. Am J Surg Pathol 2000;24:197-202.

11 Trojani M, Guiu M, Trovette H, et al. Malignant adenomyoepithelioma of the breast. An immunohistochemical, cytophotometric, and ultrastructural study of a case with lung metastases. Am J Clin Pathol 1992;98:598-602.

12 Arpino G, Clark GM, Mohsin S, et al. Adenoid cystic carcinoma of the breast: molecular markers, treatment, and clinical outcome. Cancer 2002;94:2119-27.

13 Pastolero G, Hanna W, Zbieranowski I, et al. Proliferative activity and p53 expression in adenoid cystic carcinoma of the breast. Mod Pathol 1996;9:215-19.

14 Nomura K, Fukunaga M, Uchida K, et al. Adenomyoepithelioma of the breast with exaggerated proliferation of epithelial cells: report of a case. Pathol Int 1996:46:1011-14.

15 Perou CM, Sorlie T, Eisen MB, et al. Molecular portraits of human breast tumours. Nature 2000;406:747-52.

16 Sorlie T, Perou CM, Tibshirani R, et al. Gene expression patterns of breast carcinomas distinguish tumor subclasses with clinical implications. Proc Natl Acad Sci U S A 2001;98:10869-74.

17 Toth J. Benign human mammary myoepithelioma. Virchows Arch A Pathol Anat Histol 1977;374:263-9.

18 Enghardt $\mathbf{M H}$, Hale JH. An epithelial and spindle cell breast tumour of myoepithelial origin. An immunohistochemical and ultrastructural study. Virchows Arch A Pathol Anat Histopathol 1989;416:177-84. 
19 Magro G, Bisceglia M, Michal M, et al. Spindle cell lipoma-like tumor, solitary fibrous tumor and myofibroblastoma of the breast: a clinico-pathological analysis of 13 cases in favor of a unifying histogenetic concept. Virchows Arch 2002;440:249-60.

20 Al-Nafussi A. Spindle cell tumours of the breast: practical approach to diagnosis. Histopathology 1999;35:1-13.

21 McMenamin ME, DeSchryver K, Fletcher CD. Fibrous lesions of the breast: a review. Int J Surg Pathol 2000;8:99-108.

22 Narita T, Matsuda K. Pleomorphic adenoma of the breast: case report and review of the literature. Pathol Int 1995:45:441-7.

23 Simha MR, Doctor VM, Udwadia TE. Mixed tumor of salivary gland type of the male breast. Indian J Cancer 1992;28:14-17.

24 Makek M, von Hochstetter AR. Pleomorphic adenoma of the human breast. J Surg Oncol 1980;14:281-6.

25 Diaz NM, McDivitt RW, Wick MR. Pleomorphic adenoma of the breast: a clinicopathologic and immunohistochemical study of 10 cases. Hum Pathol 1991;22:1206-14.

26 Moran CA, Suster S, Carter D. Benign mixed tumors (pleomorphic adenomas) of the breast. Am J Surg Pathol 1990;14:913-21.

27 Williams RW, Leach WB. Mixed tumor of female breast of unusual duration and size. South Med J 1975:68:97-100.

28 Parham DM, Evans A. Pleomorphic adenoma of the breast, a potential for the misdiagnosis of malignancy on fine needle aspiration (FNA). Cytopathology 1998;9:343-8

29 Agnantis NJ, Maounis N, Priovolou-Papaevangelou M, et al. Pleomorphic adenoma of the human female breast. Pathol Res Pract 1992; 188:235-40

30 van der Walt JD, Rohlova B. Pleomorphic adenoma of the human breast. A report of a benign tumour closely mimicking a carcinoma clinically. Clin Oncol 1982;8:361-5.

31 Smith BH, Taylor HB. The occurrence of bone and cartilage in mammary tumors. Am J Clin Pathol 1969;51:610-18.

32 Spagnolo DV, Shilkin KB. Breast neoplasms containing bone and cartilage. Virchows Arch A Pathol Anat Histopathol 1983;400:287-95

33 Geurts JM, Schoenmakers EF, Roijer E, et al. Expression of reciprocal hybrid transcripts of HMGIC and FHIT in a pleomorphic adenoma of the parotid gland. Cancer Res 1997;57:13-17

34 Voz ML, Agten NS, Van de Ven WJ, et al. PLAG1, the main translocation target in pleomorphic adenoma of the salivary glands, is a positive regulator of IGF-II. Cancer Res 2000;60:106-13.

35 Soreide JA, Anda O, Eriksen L, et al. Pleomorphic adenoma of the human breast with local recurrence. Cancer 1988;61:997-1001.

36 Czader M, Eberhart CG, Bhatti N, et al. Metastasizing mixed tumor of the parotid: initial presentation as a solitary kidney tumor and ultimate carcinomatous transformation at the primary site. Am J Surg Pathol 2000; 24: 1 159-64

37 Finner RL, Hammond EH. The myoepithelial cell in lesions of the breast. Pathol Annu 1993;28(pt2): 145-69.

38 Foschini MP, Fulcheri E, Baracchini $P$, et al. Squamous cell carcinoma with prominent myxoid stroma. Hum Pathol 1990;21:859-65.

39 Wargotz ES, Norris HJ. Metaplastic carcinomas of the breast. I. Matrix-producing carcinoma. Hum Pathol 1989;20:628-35.

40 Azzopardi JG. Problems in breast pathology. In: Azzopardi JG, Bennington JL, eds. Major problems in pathology. London: WB Saunders, 1979 .

41 Miliauskas JR, Leong AS. Adenoid cystic carcinoma in a juvenile male breast. Pathology 1991;23:298-301.

42 Lamovec J, Us-Krasovec M, Zidar A, et al. Adenoid cystic carcinoma of the breast: a histologic, cytologic, and immunohistochemical study. Semin Diagn Pathol 1989:6:153-64.

43 Tavassoli FA, Norris HJ. Mammary adenoid cystic carcinoma with sebaceous differentiation. A morphologic study of the cell types. Arch Pathol Lab Med 1986;1 10:1045-53.

44 Van Dorpe J, De Pauw A, Moerman P. Adenoid cystic carcinoma arising in an adenomyoepithelioma of the breast. Virchows Arch 1998:432: 119-22.

45 Rosen PP. Adenoid cystic carcinoma of the breast. A morphologically heterogeneous neoplasm. Pathol Annu 1989;24(Pt 2):237-54.

46 Page DL, Dixon JM, Anderson TJ, et al. Invasive cribriform carcinoma of the breast. Histopathology 1983;7:525-36.

47 Gokaslan ST, Carlile B, Dudak M, et al. Solitary cylindroma (dermal analog tumor) of the breast: a previously undescribed neoplasm at this site. Am J Surg Pathol $2001 ; 25: 823-6$.

48 Reis Filho JS, Schmitt FC. Taking advantage of basic research: p63 is a reliable myoepithelial and stem cell marker. Adv Anat Pathol 2002;9:280-9

49 Reis-Filho JS, Milanezi F, Silva P, et al. Maspin expression in myoepithelial tumors of the breast. Pathol Res Pract 2001;197:817-21.

50 Wells CA, Nicoll S, Ferguson DJ. Adenoid cystic carcinoma of the breast: a case with axillary lymph node metastasis. Histopathology $1986 ; 10: 415-24$

51 Zaloudek C, Oertel YC, Orenstein JM. Adenoid cystic carcinoma of the breast. Am J Clin Pathol 1984;81:297-307.

52 Kasami M, Olson SJ, Simpson JF, et al. Maintenance of polarity and a dual cell population in adenoid cystic carcinoma of the breast: an immunohistochemical study. Histopathology 1998;32:232-8.

53 Mark HF, Hanna I, Gnepp DR. Cytogenetic analysis of salivary gland type tumors. Oral Surg Oral Med Oral Pathol Oral Radiol Endod 1996;82:187-192

54 Yamamoto $Y$, Wistuba II, Kishimoto $Y$, et al. DNA analysis at p53 locus in adenoid cystic carcinoma: comparison of molecular study and p53 immunostaining. Pathol Int 1998;48:273-80.
55 Holst VA, Marshall CE, Moskaluk CA, et al. KIT protein expression and analysis of c-kit gene mutation in adenoid cystic carcinoma. Mod Pathol 1999; 12:956-60.

56 Ro JY, Silva EG, Gallager HS. Adenoid cystic carcinoma of the breast. Hum Pathol 1987:18:1276-81

57 Qizilbash AH, Patterson MC, Oliveira KF. Adenoid cystic carcinoma of the breast. Light and electron microscopy and a brief review of the literature. Arch Pathol Lab Med 1977;101:302-6.

58 Colome MI, Ro JY, Ayala AG, et al. Adenoid cystic carcinoma of the breast metastatic to the kidney. J Urol Pathol 1996;4:69-78.

59 Kleer CG, Oberman HA. Adenoid cystic carcinoma of the breast: value of histologic grading and proliferative activity. Am J Surg Pathol 1998;22:569-75.

60 Shin SJ, Rosen PP. Solid variant of mammary adenoid cystic carcinoma with basaloid features: a study of nine cases. Am J Surg Pathol 2002;26:413-20.

61 Rosen PP, Ernsberger D. Low-grade adenosquamous carcinoma. A variant of metaplastic mammary carcinoma. Am J Surg Pathol 1987;11:351-8.

62 Drudis T, Arroyo C, Van Hoeven K, et al. The pathology of low-grade adenosquamous carcinoma of the breast. An immunohistochemical study. Pathol Annu 1994:29:181-97.

63 Van Hoeven KH, Drudis T, Cranor ML, et al. Low-grade adenosquamous carcinoma of the breast. A clinicopathologic study of 32 cases with ultrastructural analysis. Am J Surg Pathol 1993;17:248-58.

64 Reis Filho JS, Milanezi F, Paredes J, et al. Novel and classic myoepithelial/stem cell markers in metaplastic carcinomas of the breast. Appl Immunohistochem Mol Morphol 2003;1 1:1-8.

65 Seifert G. Are adenomyoepithelioma of the breast and epithelial-myoepithelial carcinoma of the salivary glands identical tumours? Virchows Arch 1998:433:285-8.

66 Kiaer H, Nielsen B, Paulsen S, et al. Adenomyoepithelial adenosis and low-grade malignant adenomyoepithelioma of the breast. Virchows Arch A Pathol Anat Histopathol 1984;405:55-67.

67 Eusebi V, Casadei GP, Bussolati G, et al. Adenomyoepithelioma of the breast with a distinctive type of apocrine adenosis. Histopathology 1987;1 1:305-15.

68 Rosen PP. Adenomyoepithelioma of the breast. Hum Pathol 1987; 18:1232-7.

69 Tamura G, Monma N, Suzuki Y, et al. Adenomyoepithelioma (myoepithelioma) of the breast in a male. Hum Pathol 1993;24:678-81.

70 Berna JD, Arcas I, Ballester A, et al. Adenomyoepithelioma of the breas in a male. AJR Am J Roentgenol 1997;169:917-18.

71 Tsuda H, Mukai K, Fukutomi T, et al. Malignant progression of adenomyoepithelial adenosis of the breast. Pathol Int 1994;44:475-9.

72 Eusebi V, Foschini MP, Betts CM, et al. Microglandular adenosis, apocrine adenosis, and tubular carcinoma of the breast. An immunohistochemical comparison. Am J Surg Pathol 1993;17:99-109.

73 Page DL, Simpson JF. What is apocrine adenosis, anyway? Histopathology 2001;39:433-4.

74 Wells CA, McGregor IL, Makunura CN, et al. Apocrine adenosis: a precursor of aggressive breast cancer? J Clin Pathol 1995;48:737-42.

75 Fonseca I, Soares J. Epithelial-myoepithelial carcinoma of the salivary glands. A study of 22 cases. Virchows Arch A Pathol Anat Histopathol 1993:422:389-96.

76 Fonseca I, Soares J. Proliferation in adenomyoepitheliomas. Histopathology 1998;32:279.

77 Hamper K, Brugmann M, Koppermann R, et al. Epithelial-myoepithelial duct carcinoma of salivary glands: a follow-up and cytophotometric study of 21 cases. J Oral Pathol Med 1989;18:299-304.

78 Loose JH, Patchefsky AS, Hollander IJ, et al. Adenomyoepithelioma of the breast. A spectrum of biologic behavior. Am J Surg Pathol $1992 ; 16: 868-76$

79 Foschini MP, Pizzicannella G, Peterse JL, et al. Adenomyoepithelioma of the breast associated with low-grade adenosquamous and sarcomatoid carcinomas. Virchows Arch 1995:427:243-50.

80 Rasbridge SA, Millis RR. Adenomyoepithelioma of the breast with malignant features. Virchows Arch 1998;432:123-30.

81 Michal M, Baumruk L, Burger J, et al. Adenomyoepithelioma with undifferentiated component. Histopathology 1994;24:274-6.

82 Pawels $\mathbf{P}$, DePotter $\mathrm{C}$. Adenomyoepithelioma of the breast with features of malignancy. Histopathology 1994;24:94-6.

83 Kinkor Z. Myoepithelial carcinoma in adenomyoepithelioma of the breast (malignant adenomyoepithelioma) - case report. Cesk Patol 2002;38:46-50.

84 Simpson RH, Cope N, Skalova A, et al. Malignant adenomyoepithelioma of the breast with mixed osteogenic, spindle cell, and carcinomatous differentiation. Am J Surg Pathol 1998;22:631-6.

85 Ahmed AA, Heller DS. Malignant adenomyoepithelioma of the breast with malignant proliferation of epithelial and myoepithelial elements: a case report and review of the literature. Arch Pathol Lab Med 2000; 124:632-6.

86 Bult P, Verwiel JM, Wobbes T, et al. Malignant adenomyoepithelioma of the breast with metastasis in the thyroid gland 12 years after excision of the primary tumor. Case report and review of the literature. Virchows Arch 2000:436:158-66.

87 Sugano I, Nagao T, Tajima Y, et al. Malignant adenomyoepithelioma of the breast: a non-tubular and matrix-producing variant. Pathol Int 2001;51:193-9.

88 Lakhani SR, O'Hare M, Monaghan P, et al. Malignant myoepithelioma (myoepithelial carcinoma) of the breast: a detailed cytokeratin study. J Clin Pathol 1995;48: 164-7. 
89 Cartagena N, Jr, Cabello-Inchausti B, Willis I, et al. Clear cell myoepithelial neoplasm of the breast. Hum Pathol 1988;19:1239-43. 90 Maiorano E, Ricco R, Virgintino D, et al. Infiltrating myoepithelioma of the breast. Appl Immunohistochem 1994;2:130-6.

91 Rode L, Nesland JM, Johannessen JV. A spindle cell breast lesion in a 54-year-old woman. Ultrastruct Pathol 1986;10:421-5.

92 Scarpellini F, Usellini L, Foschini MP. Malignant myoepithelioma associated with in situ and invasive ductal carcinoma. Description of a case and review of the literature. Pathologica 1997;89:420-4.

93 Schurch W, Potvin C, Seemayer TA. Malignant myoepithelioma (myoepithelial carcinoma) of the breast: an ultrastructural and immunocytochemical study. Ultrastruct Pathol 1985;8:1-11.

94 Shiroishi T, Nakayama T, Fukutoma K, et al. Malignant myoepithelioma of the breast metastasizing to the jaw. Virchows Arch 1999:435:520-3.

95 Tamai $M$. Intraductal growth of malignant mammary myoepithelioma. Am J Surg Pathol 1992;16:1116-25.

96 Soares J, Tomasic G, Bucciarelli E, et al. Intralobular growth of myoepithelial cell carcinoma of the breast. Virchows Arch 1994;425:205-10

97 Thorner PS, Kahn HJ, Baumal R, et al. Malignant myoepithelioma of the breast. An immunohistochemical study by light and electron microscopy. Cancer 1986;57:745-50

98 Savera AT, Prasad AR, Zarbo RJ. Myoepithelial carcinoma of the breast: a clinicopathologic study of 18 cases [abstract]. Mod Pathol 2000; 13:46A

99 Foschini MP, Dina RE, Eusebi V. Sarcomatoid neoplasms of the breast: proposed definitions for biphasic and monophasic sarcomatoid mammary carcinomas. Semin Diagn Pathol 1993;10:128-36.

100 Damiani S, Riccioni L, Pasquinelli G, et al. Poorly differentiated myoepithelial cell rich carcinoma of the breast. Histopathology 1997:30:542-8

101 Damiani S, Dina R, Eusebi V. Eosinophilic and granular cell tumors of the breast. Semin Diagn Pathol 1999;16:117-25

102 Skalova A, Michal M, Ryska A, et al. Oncocytic myoepithelioma and pleomorphic adenoma of the salivary glands. Virchows Arch 1999:434:537-46

103 Lakhani SR, Chaggar R, Davies S, et al. Genetic alterations in "normal" luminal and myoepithelial cells of the breast. J Pathol 1999;189:496503.

104 Sternlicht MD, Barsky SH. The myoepithelial defense: a host defense against cancer. Med Hypotheses 1997;48:37-46.

105 Sternlicht MD, Kedeshian P, Shao ZM, et al. The human myoepithelial cell is a natural tumor suppressor. Clin Cancer Res 1997;3:1949-58.

106 Barbareschi M. Pecciarini L, Cangi MG et al. p63, a p53 homologue, is a selective nuclear marker of myoepithelial cells of the human breast. Am J Surg Pathol 2001;25:1054-60.

107 Wang X, Mori I, Tang W, et al. Metaplastic carcinoma of the breast: p53 analysis identified the same point mutation in the three histologic components. Mod Pathol 2001;14:1183-6.

108 Reis Filho JS, Schmitt FC. p63 expression in sarcomatoid/metaplastic carcinomas of the breast. Histopathology 2003;42:94-5

109 Patturajan M, Nomoto S, Sommer M, et al. DeltaNp63 induces beta-catenin nuclear accumulation and signaling. Cancer Cell 2002;1:369-79.

110 Dardick I, Gliniecki MR, Heathcote JG, et al. Comparative histogenesis and morphogenesis of mucoepidermoid carcinoma and pleomorphic adenoma. An ultrastructural study. Virchows Arch A Pathol Anat Histopathol 1990;417:405-17.

111 Dardick I, Daya D, Hardie J, et al. Mucoepidermoid carcinoma: ultrastructural and histogenetic aspects. J Oral Pathol 1984;13:342-58.

112 Foschini MP, Marucci G, Eusebi V. Low-grade mucoepidermoid carcinoma of salivary glands: characteristic immunohistochemical profile and evidence of striated duct differentiation. Virchows Arch 2002;440:536-42
113 Hanna W, Kahn HJ. Ultrastructural and immunohistochemical characteristics of mucoepidermoid carcinoma of the breast. Hum Pathol 1985; 16:941-6.

114 Seifert G, Brocheriou C, Cardesa A, et al. WHO international histological classification of tumors. Tentative classification of salivary gland tumors. Pathol Res Pract 1990;186:555-81.

115 Roncaroli F, Lamovec J, Zidar A, et al. Acinic cell-like carcinoma of the breast. Virchows Arch 1996:429:69-74.

116 Schmitt FC, Ribeiro CA, Alvarenga S, et al. Primary acinic cell-like carcinoma of the breast-a variant with good prognosis? Histopathology 2000;36:286-9.

117 Damiani S, Pasquinelli G, Lamovec J, et al. Acinic cell carcinoma of the breast: an immunohistochemical and ultrastructural study. Virchows Arch 2000;437:74-81.

118 Hirokawa M, Sugihara K, Sai T, et al. Secretory carcinoma of the breast: a tumour analogous to salivary gland acinic cell carcinoma? Histopathology 2002;40:223-9.

119 Coyne JD, Dervan PA. Primary acinic cell carcinoma of the breast. J Clin Pathol 2002;55:545-7

120 Damiani S, Eusebi V, Losi L, et al. Oncocytic carcinoma (malignant oncocytoma) of the breast. Am J Surg Pathol 1998:22:221-30.

121 Costa MJ, Silverberg SG. Oncocytic carcinoma of the male breast. Arch Pathol Lab Med 1989;113:1396-9.

122 Foote FW, Becker WF, Stewart FW. Muco-epidermoid tumors of salivary glands. Ann Surg 1945:122:820-44.

123 Auclair PL, Goode RK, Ellis GL. Mucoepidermoid carcinoma of intraoral salivary glands. Evaluation and application of grading criteria in 143 cases. Cancer 1992;69:2021-30.

124 Patchefsky AS, Fravenhoffer CM, Krall RA, et al. Low-grade mucoepidermoid carcinoma of the breast. Arch Pathol Lab Med 1979;103:196-8.

125 Fisher ER, Palekar AS, Gregorio RM, et al. Mucoepidermoid and squamous cell carcinomas of breast with reference to squamous metaplasia and giant cell tumors. Am J Surg Pathol 1983;7:15-27.

126 Kovi J, Duong HD, Leffall LS, Jr. High-grade mucoepidermoid carcinoma of the breast. Arch Pathol Lab Med 1981;105:612-14.

127 Ratanarapee S, Prinyar-Nussorn N, Chantarakul N, et al. High-grade mucoepidermoid carcinoma of the breast. A case report. J Med Assoc Thai 1983;66:642-8

128 Leong AS, Williams JA. Mucoepidermoid carcinoma of the breast: high grade variant. Pathology 1985;17:516-21.

129 Hastrup N, Sehested M. High-grade mucoepidermoid carcinoma of the breast. Histopathology 1985;9:887-92.

130 Pettinato G, Insabato L, De Chiara A, et al. High-grade mucoepidermoid carcinoma of the breast. Fine needle aspiration cytology and clinicopathologic study of a case. Acta Cytol 1989;33:195-200

131 Berry MG, Caldwell C, Carpenter R. Mucoepidermoid carcinoma of the breast: a case report and review of the literature. Eur J Surg Oncol 1998;24:78-80.

132 Markopoulos C, Gogas H, Livaditou A, et al. Mucoepidermoid carcinoma of the breast. Eur J Gynaecol Oncol 1998;19:291-3.

133 Chang LC, Lee N, Lee CT, et al. High-grade mucoepidermoid carcinoma of the breast: case report. Changgeng Yi Xue Za Zhi 1998;21:352-7.

134 Luchtrath H, Moll R. Mucoepidermoid mammary carcinoma. Immunohistochemical and biochemical analyses of intermediate filaments. Virchows Arch A Pathol Anat Histopathol 1989;416:105-13.

135 Luchtrath H. Mucoepidermoid cancer of the breast. Pathologe 1984;5:282-4.

136 Goode RK, Auclair PL, Ellis GL. Mucoepidermoid carcinoma of the major salivary glands: clinical and histopathologic analysis of 234 cases with evaluation of grading criteria. Cancer 1998;82:1217-24. 


\section{CORRESPONDENCE}

If you have a burning desire to respond to a paper published in Journal of Clinical Pathology, why not make use of our "rapid response" option?

Log on to our website (www.jclinpath.com), find the paper that interests you, and send your response via email by clicking on the "eletters" option in the box at the top right hand corner.

Providing it isn't libellous or obscene, it will be posted within seven days. You can retrieve it by clicking on "read eletters" on our homepage.

The editors will decide as before whether to also publish it in a future paper issue.

\section{Metastasis of solid tumours in bone marrow: a study from Kashmir, India}

Between 1935 and 2001, many studies have appeared in the literature from different parts of the world on bone marrow invasion by solid tumours. ${ }^{1-4}$ After lymphoma, the primary tumours that most frequently involve the bone marrow are malignancies of the prostate, breast, lungs, thyroid, kidney, and stomach. ${ }^{4}$ Metastatic deposits of malignant melanoma have also been described. ${ }^{3}$ In many instances, primary tumours remain clinically undetected and are identified only at necropsy. ${ }^{1}$

The value of bone marrow aspiration in the diagnosis of malignant neoplasms was confirmed when four of eight cases of malignant melanoma were found to harbour tumour deposits in the bone marrow. ${ }^{3}$ In a series of 57 patients with known carcinoma of the prostate, five had carcinoma cells in the bone marrow, with no other diagnostic evidence of skeletal system involvement. ${ }^{2}$ The usefulness of such a comparatively simple procedure is emphasised by studies of large series of patients with known malignancies, ${ }^{23}$ especially when the primary tumour is known to have a predilection for the skeletal system.

The patients in the abovementioned studies had known primary tumours and at present bone marrow aspiration/biopsy is routinely performed for staging of tumours, but the high incidence of metastatic deposits found in these bone marrows ${ }^{2-4}$ emphasises the practicability of routine bone marrow aspiration in patients with suspected malignancy or severe anaemia. It is difficult to determine from the literature the incidence of malignant cells in routine series of unselected bone marrow aspirates, so we investigated the usefulness of routine bone marrow examination for the diagnosis of malignancies.

A one year prospective study covering the year 2001 was conducted in the department of pathology, Government Medical College, Srinagar, Kashmir, India. The bone marrow smears were routinely stained by Leishman's stain and Perl's reaction. Periodic acid Schiff and Sudan black stain were used as and when required. Of the 318 bone marrow samples studied during the year 2001, eight cases contained metastatic deposits. All of the patients in our present study had pallor (anaemia) as one of the main symptoms, and underwent bone marrow aspiration to determine which type of anaemia they were suffering from. In patients with metastatic deposits the normal haemopoietic cells of the bone marrow are replaced by tumour cells, resulting in myelopathesic anaemia, and later on they are liable to develop myeloid metaplasia and myelofibrosis. In most of the cases, the bone marrow was difficult to aspirate, especially in cases of epithelial cell deposits, with mostly cancerous cells obtained in a background of peripheral blood - a fact that has already been reported. ${ }^{4}$

After leukaemia, lymphoma most commonly involves the bone marrow and almost $10 \%$ of cases of lymphoma invade the bone marrow. In our present study, lymphoma (non-Hodgkin lymphoma) made up a quarter (two cases) of all the secondary tumours of the bone marrow, along with neuroblastoma (two cases) - a childhood tumour. Neuroblastoma, non-Hodgkin lymphoma, and acute lymphoblastic leukaemia pose a considerable amount of difficulty in diagnosis because all three are round cell tumours with a very similar morphological appearance. In acute lymphoblastic leukaemia, the peripheral blood film examination is of paramount importance because it shows the presence of lymphoblasts, whereas neuroblastoma cells in bone marrow smears tend to form rosettes and may show neural or neurofibrillary differentiation. Non-Hodgkin lymphoma is thought of as a malignancy of old age, although it can be seen at any age; however, childhood lymphomas are mostly of high grade

In most studies, the incidence of tumour deposits in the bone marrow from gastrointestinal tumours was low, but they made up a quarter of the cases presented here (two cases). This could be explained by the low number of cases in our study, together with the high incidence of gastrointestinal cancers, especially of the oesophagus and stomach seen in Kashmir. ${ }^{5}$ Deposits from prostate and breast tumours (one case each) are known to have a predilection for skeletal metastasis.

Finally, several features worthy of comment are that the metastatic tumour cells are easily identified in the bone marrow smears because they look foreign within the native bone marrow cell population. These cells are usually identified in groups, even at low power examination, because they are larger than most of the bone marrow cells. Single cells are more difficult to recognise, although they never resemble the normal bone marrow cells. The primary site of the malignant deposits may be extremely difficult to determine on a morphological basis only, but their origin can sometimes be inferred from their morphological appearance, especially in mucous producing carcinoma, squamous carcinoma, some adenocarcinomas, and in many cases of metastatic neuroblastoma or melanoma.

R A Tasleem, N D Chowdhary

Department of Pathology, Government Medical College, Srinagar 190001, Kashmir, India kadrism@sancharnet.in
S M Kadri

Department of Microbiology, Government Medical College, Srinagar

Q A Chowdhary

Government Medical College, Srinagar

\section{References}

1 Reich C. A study of the diagnostic value of sternal puncture in clinical hematology. Am J Med 1935; 189:515-20.

2 Clifton JA, Philip RJ, Ludovac E, et al. Bone marrow and carcinoma prostate. Am J M Sci 1952;224:121-30

3 Motulsky AG, Rohn RJ. The bone marrow in metastatic malignant melanoma. J Lab Clin Med 1953:41:526-33.

4 Ghazi Aasia I, Chowdhary ND, Laharwal MA. Metastatic carcinoma of bone marrow in Kashmir. JK Pract 2001;8:88-9.

5 Shah A, Jan GM. Pattern of cancer at Srinagar (Kashmir). Indian J Pathol Microbiol 1990;33:118-23.

\section{Fatal water intoxication}

Water intoxication can occur in a variety of different clinical settings but is generally not well recognised in the medical literature. The condition may go unrecognised in the early stages when the patient may have symptoms of confusion, disorientation, nausea, and vomiting, but also changes in mental state and psychotic symptoms. Early detection is crucial to prevent severe hyponatraemia, which can lead to seizures, coma, and death.

The patient reported here was a 64 year old woman with a known history of mitral valve disease but no other relevant past history. On the evening before her death, she began compulsively drinking water in vast quantities, estimated at between 30 and 40 glasses, and this was interspersed with episodes of vomiting. She became hysterical and also distressed, shouting that she had not drunk enough water. She declined medical attention but continued to drink water after she had gone to bed. She later fell asleep and died some time later.

A postmortem examination was carried out six hours later. The pituitary and adrenal glands were normal and there was no evidence of a bronchial tumour. There were bilateral pleural effusions of $200 \mathrm{ml}$ on each side and the cut surfaces of the lungs (568 g and $441 \mathrm{~g}$ ) exuded frothy pink fluid. The heart $(46 \mathrm{lg})$ showed evidence of mitral valve disease and left ventricular hypertrophy. Within the stomach there was $800 \mathrm{ml}$ of watery fluid and the intra-abdominal organs were generally wet.

Postmortem toxicology was negative. A sample of vitreous humour showed a sodium concentration of $92 \mathrm{mmol} / \mathrm{litre}$ (serum reference range, 132-144). Potassium, urea, and glucose were all within the serum reference ranges. Blood cortisol was raised, excluding an addisonian crisis.

The cause of death was given as hyponatraemia as a result of acute water intoxication.

Water intoxication provokes disturbances in electrolyte balance, resulting in a rapid decrease in serum sodium concentration and eventual death. The development of acute dilutional hyponatraemia causes neurological symptoms because of the movement of water into the brain cells, in response to the fall in 
extracellular osmolality. Symptoms can become apparent when the serum sodium falls below $120 \mathrm{mmol} /$ litre, but are usually associated with concentrations below $110 \mathrm{mmol} /$ litre. Severe symptoms occur with very low sodium concentrations of 90-105 mmol/litre. As the sodium concentration falls, the symptoms progress from confusion to drowsiness and eventually coma. However, the rate at which the sodium concentration falls is also an important factor, and the acute intake of large volumes of water over a short period of time, as occurred in this case, would have produced a rapid drop in serum sodium, which was fatal.

Postmortem serum samples are unsuitable for sodium measurement because concentrations decrease after death and there is considerable individual variation. However, vitreous sodium concentrations are stable in the early postmortem period, and the concentration in vitreous humour is similar to that found in normal serum. ${ }^{1}$ Studies have shown that abnormal vitreous humour sodium concentrations had corresponding antemortem hyponatraemia or hypernatreamia.

Self induced water intoxication is known to psychologists, but there is a paucity of information and little awareness of this life threatening problem in the professional literature. ${ }^{3}$ The initial symptoms associated with this condition are very similar to psychosis, with inappropriate behaviour, delusions, hallucinations, confusion, and disorientation. If untreated, the symptoms may progress from mild confusion to acute delirium seizures, coma, and death, as occurred in this case.

Fatal water intoxication has been described in several different clinical situations. The most common of these is psychogenic polydipsia (compulsive water drinking), which is sometimes associated with either menta illness or mental handicap. ${ }^{45}$ The condition has also been described in young army recruits of good health who developed hyponatraemia after apparent overhydration following heat related injuries. ${ }^{6}$ The most common symptoms suffered by this group were changes in mental status, emesis, nausea, and seizures. Accidental water intoxication has been described as a result of excessive water intake after an episode of gastroenteritis, ${ }^{7}$ and an iatrogenic case has occurred after gastric lavage. ${ }^{8}$ Forced water intoxication is a recognised form of child abuse, which commonly leads to brain damage and is sometimes fatal. ${ }^{9}$

In conclusion, we wish to highlight an unusual cause of death that may go unnoticed without an appropriate clinical history and relevant postmortem biochemical investigations. Both clinicians and pathologists need to be aware of this condition, which may manifest itself as a psychotic illness and so go unrecognised in its early stages. Early detection is crucial to prevent fatal complications.

D J Farrell

Department of Histopathology, Torbay Hospital, Lawes Bridge, Torquay, Devon, TQ2 7AA, UK desmond.farrell@sdevonhc-tr.swest.nhs.uk

L Bower

Department of Clinical Chemistry, Torbay Hospital

\section{References}

1 Coe JI. Post-mortem chemistry update. Emphasis on forensic application. Am J Forensic Med Pathol 1993:14:91-117.

2 Swift PGF, Worthy E, Emery JL. Biochemical state of the vitreous humour of infants at necropsy. Arch Dis Child 1974;49:680-5.

3 Umansky L, Sella A. Psychogenic polydipsia leading to water intoxication. Harefuah 2000; 138:9-12.

4 Cosgray RE, Hanna V, Davidhizar RE, et al. The water-intoxicated patient. Arch Psychiatr Nurs 1990;4:308-12.

5 Bremner AJ, Regan A. Intoxicated by water. Polydipsia and water intoxication in a mental handicap hospital. Br J Psychiatry $1991 ; 158: 244-50$
6 O'Brien KK, Montain SJ, Corr WP, et al. Hyponatraemia associated with overhydration in US Army trainees. Mil Med

2001;166:405-10.

7 Sjoblom E, Hojer J, Ludwigs U, et al. Fatal hyponatraemic brain oedema due to common gastroenteritis with accidental water intoxication. Intensive Care Med 1997;23:348-50.

8 Chen X, Huang G. Autopsy case report of a rare acute iatrogenic water intoxication with a review of the literature. Forensic Sci Int 1995;76:27-34

9 Arieff Al, Kronlund BA. Fatal child abuse by forced water intoxication. Pediatrics 1999; 103: 1292-5.

\section{CORRECTION}

Salivary gland-like tumours of the breast: surgical and molecular pathology. PiaFoschini M, Reis-Filho JS, Eusebi V, et al. J Clin Pathol 2003;56:497-506. The name of the first author should have been Foschini MP not Pia-Foschini $M$.

\section{CALENDAR OF EVENTS}

Full details of events to be included should be sent to Maggie Butler, Technical Editor JCP, The Cedars, 36 Queen Street, Castle Hedingham, Essex CO9 3HA, UK; email:maggie.butler2@btopenworld.com

\section{Medicare India}

6-8 April 2004, Pragati Maidan, New Delhi, India

Further details: Rob Grant, Kinex Log, 5 New Quebec Street, London W1H 7DD, UK (Tel: +44 (0) 207723 8020; Fax: +44 (0) 207723 8060; Email: rob.grant@kinexlog.com; Website: www.medicare-expo.com or www.kinex$\log . \mathrm{com})$ 